\title{
Environmental management systems in the architectural, engineering and construction sectors: a roadmap to aid the delivery of the sustainable development goals
}

\author{
Rosemary Horry ${ }^{1,2}$ (D) Colin A. Booth ${ }^{2}$ (D) - Abdul-Majeed Mahamadu² . \\ Patrick Manu ${ }^{3}$ (i) . Panos Georgakis ${ }^{4}$ (D)
}

Received: 7 January 2021 / Accepted: 28 September 2021 / Published online: 24 October 2021

(C) The Author(s) 2021

\begin{abstract}
Realisation of the sustainable development goals (SDGs) will provide improvements to people's lives and longevity of the planet. The architectural, engineering and construction (AEC) sectors have a potentially huge role in aiding the delivery of many SDGs; however, there appears to be a lack of research into the engagement within this sector. The leading environmental management system (EMS), ISO 14001, can enable organisations in the AEC sectors to improve their business operations, whilst minimising their impacts on the environment and improving society. Therefore, the study sets out to use institutional theory to determine the usefulness of ISO 14001 as a tool within the AEC sector and to demonstrate how the organisational benefits could facilitate the delivery of the SDGs. A stepwise PRISMA review process facilitated the compiling of academic articles and professional reports $(n=44)$, which enabled the creation of an inventory of the perceived benefits $(n=85)$ and the recognised barriers $(n=63)$ to implementing ISO 14001 across the AEC sectors. These barriers and benefits were confirmed by environmental practitioners as being relevant to the incorporation of an EMS. The most widely reported benefits within the AEC sectors were improving environmental performance and compliance with legislation. Lack of government pressure and lack of expertise were the most widely reported barriers, followed by cost to AEC organisations utilising an EMS. Following on from this inventory of benefits, it was possible to develop of a conceptual roadmap, which illustrates where linkages exist with the SDGs. SDG 4, 8, 12 and 13 are shown as exhibiting the most associations with the benefits. This roadmap was reviewed by AEC sector professionals who confirmed its usefulness. Therefore, it is surmised that the roadmap could aid strategic organisational sustainable planning or for organisations to demonstrate the delivery of their corporate social responsibilities.
\end{abstract}

Keywords ISO $14001 \cdot$ PRISMA · Sustainability $\cdot$ Corporate social responsibility

Rosemary Horry

r.e.horry@derby.ac.uk

Extended author information available on the last page of the article 


\section{Introduction}

Since the 1970s, the extraction of natural resources has increased threefold and estimations show that by 2060 material use could further double to 190 billion tonnes and greenhouse gases could increase by 43\% (UN, 2019). Data from the United Nations (UN) (2019) suggest that extraction and processing of materials, fuels and food produces half of the total global greenhouse gases and this together with water stress is responsible for more than $90 \%$ of biodiversity loss. Othman and Nadim (2010) noted that the AEC sectors use around $50 \%$ of the natural resources consumed, utilise $40 \%$ of the energy generated and produce $50 \%$ of the waste created globally. This makes the building sector a significant contributor to harmful emissions (Ade and Rehm, 2019; Cucuzzella, 2009). Furthermore, the building sector also consumes $12 \%$ of freshwater and $30 \%$ of raw materials and it is responsible for around $20 \%$ of wastewater and up to $40 \%$ of landfill waste globally (Ade and Rehm, 2019). It is, therefore, clear that the AEC sectors have enormous potential for making a considerable impact in terms of sustainability in a positive or negative manner.

The UN, (2020a) estimated that in terms of most vulnerable countries (MVC) and their populations, in 2020, another 71 million people would be pushed back into poverty and that 2.2 billion people would lack safe drinking water. Water scarcity could displace 700 million people by 2030 (UN, 2020b). The Circle Economy, (2020) notes that 50.8 billion tonnes of minerals are consumed each year and $38.8 \%$ of that goes into housing. Along with these data, the Waste Framework Directive 2008/98/EC states that all European Union (EU) member countries need to achieve at least $70 \%$ re-use, recycling, or other recovery of non-hazardous Construction and Demolition Waste (CDW) by 2020. These figures suggest that the AEC sectors have a huge impact on sustainability and through their efforts could make a huge contribution to the fulfilment of the SDG objectives, by utilising a cradle-tocradle approach (McDonough and Braungart, 2002). This study sets out to use institutional theory to determine the usefulness of ISO 14001 as a tool within the AEC sector and to demonstrate how the organisational benefits could facilitate the delivery of the SDGs.

Sustainability within the AEC sectors, particularly within construction, has received increasing attention over recent years (Berardi, 2012). AEC sectors impacts will be varied, and it is acknowledged that to mitigate the potential impacts effective sustainable development action is required. Boyko et al., (2012) and Villeneuve et al., (2017) highlighted the risks these activities can impose on the natural environment and their impact in terms of the social, economic, cultural, and political dimensions of sustainability.

The current predictions suggest that by 2050, two-thirds of the global population will be living in urban areas (Mattoni et al., 2018). There is an expectation that there will be 14 new mega cities with a demand for over 500 million $\mathrm{m}^{2}$ of new office space and more than 250 million new houses (Ade and Rehm, 2019; Ding, 2008). The design and construction of these cities will have a major impact on the delivery of the SDGs and the future health of the planet.

It has been noted by researchers that for business to be truly sustainable it needs to go beyond the traditional economic approach and short-term issues (Næss, 1994; Goubran et al., 2019). Cucuzzella, (2016) has suggested a multistep framework requiring systemwide innovations to change unsustainable practices. Dyllick and Muff, (2015) proposed four levels for sustainability in business, the first being business as usual. However, this is discounted as it is generally accepted that business as usual is no longer acceptable. As a result, there are only actually three options, namely: (i) sustainability with economic considerations, (ii) sustainability with the creation of value across the pillars of sustainability, 
or (iii) focussing on the sustainability challenges to bring about a better society (Dyllick and Muff, 2015). In this paper, the SDGs are used to enable organisations to work towards solutions, using an existing standard, ISO 14001.

Environmental management systems (EMS) (particularly ISO 14001) aim to enable organisations to prevent pollution, deliver continual improvement, and comply with legislation (BSi, 2015). Although it is acknowledged that environmental standards have focused on continual improvement, they do not actually specify a level of improvement or harm reduction (i.e. pollution prevention). Therefore, they have been accused of not enabling a transformation in terms of sustainability (Brown, 2016). Others had suggested that standards are being used increasingly to create economic value, cost savings, or increased market share and opportunities for business rather than environmental improvements (Jones and Laquidara-Carr, 2018). However, it must be acknowledged that while businesses exist to create wealth, this does not mean that they cannot make a positive environmental contribution at the same time. It is possible that companies can be sustainable in terms of economics, society, and the environment. Some researchers have suggested that potential links exist between environmental rating tools and the SDGs (Alawneh et al., 2018; Gibberd, 2015). Gibberd, (2015) combined the ecological footprint criteria and the human development index to suggest a BEST index. Alawaneh et al. (2018) looked at how a combined water and energy efficiency method could be developed to assess and improve United Nations (UN) Sustainable Development Goals (SDGs) delivery. However, there has been no focus on a tool to enable companies to demonstrate the benefits that can be achieved through working on the SDGs. It must be noted that there is a risk that the benefits, which are being achieved, are those that can be delivered at the lowest cost to the organisations or that the organisations use the system as purely a public relations (PR) tool, rather than to improve their environmental performance. This has promoted the view of the standards being less effective in promoting sustainability than market mechanisms, such as carbon trading (Bon and Hutchinson, 2010). This study intends to demonstrate the opportunities that can be created using a roadmap.

The previous section has highlighted the contribution that the construction sector has in relation to the achieving of the SDGs, but it is noted that there is a lack of research in the relationship between the sectors and engagement with the SDGs (Gade and Opoku, 2020). Analytical mapping tools have been created to trace the integration of the SDGs within projects (Goubran and Cucuzzella, 2019). Thuesen and Opoku, (2018) noted that a potential route for addressing this issue within research would focus on: understanding the links between the goals, means to measure the impact of progress, working with specific projects to attain the target and knowledge transfer. But there is no mention in this or other articles of what benefits the organisation will gain from engagement with the SDGs.

Researchers have reviewed how the construction sector could contribute to the SDG work with Lynch and Mosbah, (2017) highlighting SDG 1 (no poverty), SDG 9 (industry, innovation, and infrastructure), and SDG 11 (sustainable cities and communities). Goubran et al., (2019) also notes that buildings play a part in the use of renewable energy (SDG 7), in sustainable consumption and production (SDG 12), and in climate adaptation (SDG 13). Di Foggia, (2018) agrees that SDGs 11 and 13 are the significant ones. However, if research continues to focus on standard tools and regional case studies, the findings will remain of limited use when the aim should be transformational change.

There are of course issues in terms of the potential trade-offs that could occur if organisations only focus on one or two of the SDGs as their work to improve those could have negative impacts on other targets (Allen et al., 2019; Maes et al., 2019; Moyer and Bohl, 2018). Therefore, a roadmap is necessary to ensure that companies have the tools to deliver 
effectively on the SDGs. Then they can make a positive contribution to them without negatively affecting the work of others. The aims of this study are to complete a structured review of AEC sector literature on the benefits and barriers of ISO14001 implementation; to produce a roadmap that utilises the known benefits of implementing environmental management systems in the AEC sectors; and use the road map to support the delivery of the SDGs. The question is can ISO 14001 be used to create a roadmap by organisations to aid the delivery of the SDGs?

The study used a PRISMA review of AEC literature to identify articles that were then scrutinised for known benefits and barriers of implementing environmental management systems (da Silva and Amaral, 2019). These were then endorsed by environmental experts. A roadmap linking these benefits to each of the SDGs was produced and then validated by AEC industry experts, before drawing conclusions and recommendations for future research.

The theoretical framework selected was that of institutional theory (Hoffman, 1997), which proposes that external (social and environmental) factors influence action at an institutional level (Meyer and Rowan, 1977). This suggests that organisations are in the position of being encouraged to conform to social standards of legitimacy and to abide with social expectations (Orrù et al., 1991). This theory of the need for institutional and social legitimacy will be the framework for this research. In the next section, the background to the SDGs will be reviewed, followed by the results section where the benefits and barriers of the use of ISO 14001 will be assessed in relation to the creation of the roadmap, this will be followed by the discussion and conclusions sections.

\section{Sustainable development goals}

Sustainability and environmental management have become key in our society since the Earth Summit in Rio de Janeiro in 1992 (UN, 2020c). Governments and organisations have tried a variety of ways to promote engagement with environmental sustainability from implementing legislation and issuing guidance to recommending management systems and voluntary standards. This has led to increasing interest in the implementation of schemes such as ISO 14001 to manage the environmental impacts of organisations, which not only has resulted in cost savings and better use of resources, but also brought about an increased focus on the protection of the environment (Pesce et al., 2018). ISO 14001 enables organisations to manage their impacts on the environment, through operating procedures, objectives, and a policy, which commits them to continual improvement, legal compliance, and prevention of pollution (Owolana and Booth, 2016; Johnson, 2020). It is a tool that also allows organisations to monitor and measure the positive impacts that they are having and justify their work to insurers, customers, stakeholders across the globe (Arimura et al., 2008; Nishitani, 2009) and regulators, as well as the public (Zeng et al., 2011).

This interest in the sustainability agenda from the public has increased in recent years (Erdos, 2019; Jung et al., 2020). While there was talk about sustainability prior to 1992 (Scoones, 2007), it was the Earth Summit conference in Rio that brought the subject of sustainability to the attention of the media. Following on from Rio, a roadmap for Agenda 21 was created (Spangenberg et al., 2002), which highlighted ways for society to be more sustainable in terms of social, economic, and conservation of resources (Shah, 2008). Following on from this work in 2000, there was the release of the millennium development goals (MDG), eight in total, again the focus was on poverty, gender equality, and the 
prevention of HIV/AIDS and malaria. These aimed to reduce extreme poverty and improve health by 2015 but the primary focus was on the benefits to humans (Wagstaff et al., 2006). The MDGs were reviewed in 2015 and became the SDGs. These SDGs comprise of 17 goals (Table 1) that cover relevant thematic areas (e.g. energy, water, climate, urbanisation, transport, science, and technology) based around five key themes of people, planet, prosperity, peace, and partnership (Caldés and Rodriguez-Serrano, 2018). The SDGs are more ambitious than the MDGs with a focus not just on poverty but on the human and natural environment (Gusmão Caiado et al., 2018). These goals form a voluntary approach to deliver a better society for all, but for these to be effective they must be engaged with by industries and sectors worldwide, not just governments.

In society, individuals are now more powerful in terms of their impact on companies through their purchasing power and social media. There is, therefore, both an opportunity and a risk in terms of how and whether companies engage with the SDGs. The aims and objectives of the SDGs are broader and more encompassing than is possible for any sector to achieve alone but as Goubran et al. (2019) states the construction sector has direct or indirect influence on the SDGs with $17 \%$ of the SDG targets being directly dependent and $27 \%$ indirectly dependent.

It must also be noted that the interlinkages between the various targets (Allen et al., 2019; Le Blanc, 2015; Tosun \& Leininger, 2017) could result in actions being taken to advance one goal having a detrimental impact on another goal. Maes et al. (2019) supported this by highlighting 102 SDG targets, which had links to all the goals. It should also not be assumed that the only SDGs that are impacted by the AEC sectors are SDG 15 (i.e. life on land) and SDG 11 (i.e. sustainable cities and communities) (Gusmão Caiado et al., 2018; Allen et al., 2019). There is a need for more interdisciplinary research to achieve the SDG aims and objectives as a sector and society (Salvia et al., 2019). In an analysis by Goubran et al. (2019), it was found that the sector is related to all the goals but that the largest contribution was made in respect of SDGs 6, 7, and 11. It is contested here that SDGs

Table 1 The seventeen sustainable development goals (source: UN, 2015)

\begin{tabular}{ll}
\hline$\#$ & Sustainable development goal \\
\hline SDG1 & No poverty \\
SDG2 & Zero Hunger \\
SDG3 & Good health and Well-being \\
SDG4 & Quality Education \\
SDG5 & Gender Equality \\
SDG6 & Clean Water and Sanitation \\
SDG7 & Affordable and Clean Energy \\
SDG8 & Decent work and Economic growth \\
SDG9 & Industry, Innovation and Infrastructure \\
SDG10 & Reduced Inequalities \\
SDG11 & Sustainable Cities and Communities \\
SDG12 & Responsible Consumption and Production \\
SDG13 & Climate Action \\
SDG14 & Life Below Water \\
SDG15 & Life on Land \\
SDG16 & Peace Justice and Strong Institutions \\
SDG17 & Partnerships for the goals \\
\hline
\end{tabular}


4, 8, 12, and 13 are also significantly impacted. Based on extensive literature searches, this is the first known study to demonstrate the potential opportunity of supporting the delivery of the SDGs through the utilisation of environmental management systems.

\section{Research design and methodology}

To achieve the purpose of this study, an interpretivist epistemology (Hudson and Ozanne, 1988) was used together with abductive reasoning (Bryman and Bell, 2015) with elements of positivism. In an interpretivist epistemology (Hudson and Ozanne, 1988), reality is multiple and relative, within the confines of institutional theory (Hoffman, 1997). An institutional theory approach was used as this suggests environmental problems are neither technologically or economically guided, rather they are mostly behavioural and culturally derived. While technology or economic activity may be the cause of the environmental destruction, our own beliefs, cultural norms, and societal institutions direct those activities (David, 1985). Therefore, any organisation will be influenced not only by the character of the organisation and culture itself but also the social legitimacy that comes through engagement with its stakeholders.

The research process consisted of the five stages (Figure 1). Initially, a literature review was undertaken to discover the common barriers and benefits that have been reported by other researchers in the use of ISO 14001. The review used a PRISMA evidence-based transparent process (Moher et al., 2009), whereby journal articles were identified, then screened for suitability (Table 2) before inclusion in a structured review (Liberati et al., 2009). There are many reasons for conducting a literature review (Randolph, 2009). In this study, peer-reviewed literature was the focus (Abanda et al., 2015). These findings were shared with a group of Institute of Environmental Management and Assessment (IEMA) professionals $(n=25)$ whose involvement was to confirm or refute the validity of the findings. The findings were used to create a roadmap and then a second validation process was undertaken using AEC professionals to confirm the usefulness of the roadmap in terms of the specific sectors of interest.

A range of databases (including Scopus and Web of Science, amongst others) were used to cover a variety of different discipline areas (such as engineering, business, social science). The search was limited to common phrases or keywords (such as

ISO 14001, Environmental Management Systems and EMS) within relevant fields (such as architecture, engineering, construction) and the literature search was constrained to articles from 1999 to 2020 (years inclusive), and restricted to peer-review journal papers, reviews, conference papers and book chapters, and only works published in the English language. The typical code used to search the databases was: TITLE-ABS-KEY (('ISO 14001' OR 'EMS' OR 'Environmental Management System') AND ('architecture' OR 'engineering' OR 'construction')) AND (LIMIT-TO (LANGUAGE, "English")). In this initial stage, the focus was on identifying the benefits of ISO 14001; therefore, words connected to the SDGs (and similar) were excluded from search terms, to maximise the list of possible benefits. Of the original 155 articles, some were duplications which resulted in 137. These were then reviewed by reading the abstract and introduction. Subsequently, questions were asked to clarify whether the article should be included in the study. These questions were related to the content and the research question (Table 2). The first section of questions formed exclusion criteria where all the questions had to have a positive answer. The second question section was in the form 


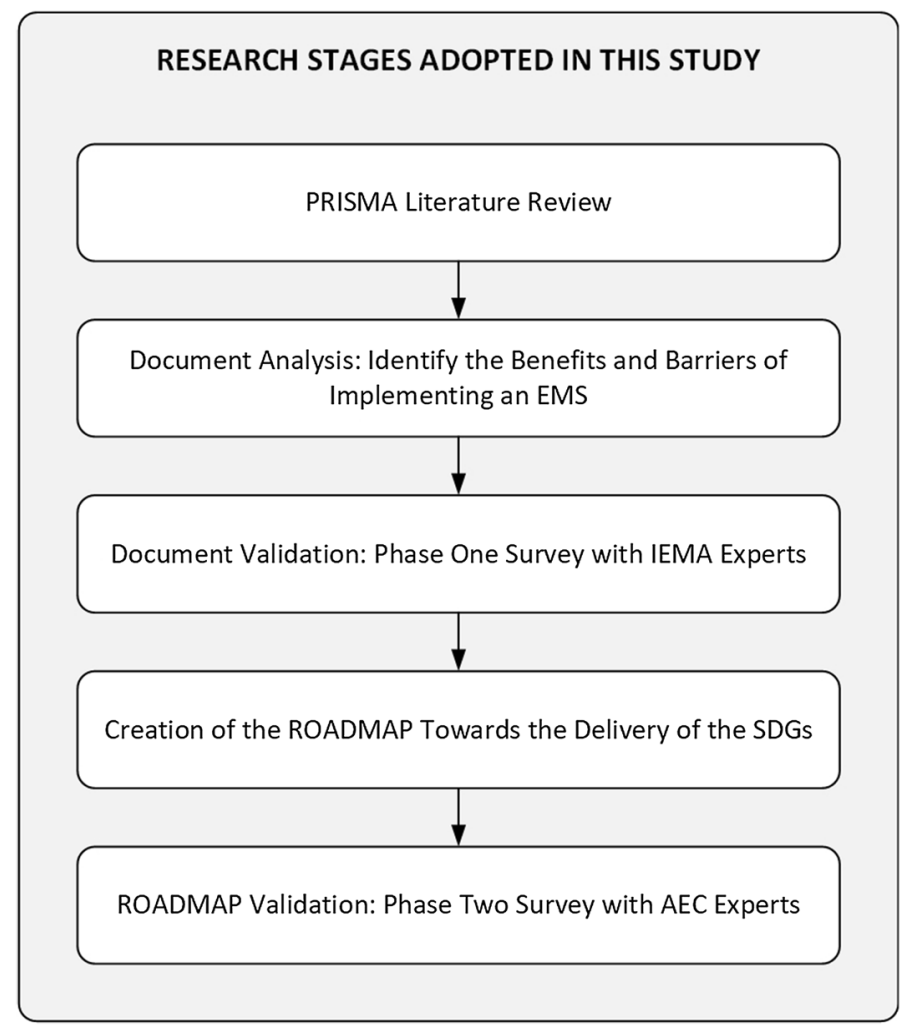

Fig. 1 Stages of the research design used in this study

Table 2 Protocol for the structured review undertaken ( adapted from da Silva \& Amaral, 2019)

\begin{tabular}{|c|c|c|}
\hline Review Phase & Data collected & Requirements and questions \\
\hline Search the data bases using keywords & $\begin{array}{l}\text { Year } \\
\text { Authors } \\
\text { Methodology } \\
\text { Sector } \\
\text { Country } \\
\text { Article type } \\
\text { Source text }\end{array}$ & \\
\hline Assessment of the content & $\begin{array}{l}\text { Objectives } \\
\text { Main results }\end{array}$ & $\begin{array}{l}\text { Yes to all questions to include the paper: } \\
\text { Does the paper focus on ISO } 14001 \text { ? } \\
\text { Is it concerned with the AEC sector? } \\
\text { Are the findings clear? }\end{array}$ \\
\hline Research question related & Research questions & $\begin{array}{l}\text { Yes to at least one question to include } \\
\text { the paper: } \\
\text { Does the study define benefits of the } \\
\text { implementation of ISO } 14001 \text { ? } \\
\text { Does the study define barriers to the } \\
\text { implementation of ISO } 14001 ?\end{array}$ \\
\hline Data extraction & $\begin{array}{l}\text { Benefits of ISO } 14001 \\
\text { Barriers of ISO } 14001\end{array}$ & \\
\hline
\end{tabular}


of inclusion criteria where at least one answer had to be positive. This resulted in 44 articles which were eligible to be included in the review.

Document analysis (Bowen, 2009) was then used to identify all the known benefits and barriers of implementing EMS in the AEC sectors. This involved a structured process of examining and interpreting the information to gain an understanding and thereby increasing knowledge (Corbin and Strauss, 2008). The information was then collated in a database and analysed, before the content was validated (Ezekannagha et al., 2020). The benefits were then reviewed to see if the same benefits could be achieved through working towards the attainment of the SDGs.

To validate the literature review, the list of benefits and barriers were shared via a Qualtrics questionnaire survey (recording participant details and opinions) with a panel of environmental experts, who were members of the Institute of Environmental Management and Assessment (IEMA) LinkedIn group. Eligibility criteria used to include participants as experts were that they needed to be: (i) an IEMA member of five years or more; (ii) hold the minimum of a Bachelor degree qualification; and (ii) be working in an environmental management role. Using the confirmed list of benefits, it was now possible to draft the roadmap to investigate whether similar benefits could be obtained by engaging with the SDGs. The incentive to use a roadmap was to provide a strategic abstract visual representation of information (Blackwell et al., 2008). Therefore, the roadmap created in this study was constructed by cross-linking each of the validated benefits of implementing ISO 14001 in the AEC sectors against each of the SDGs. Acknowledging that some of the SDG targets could be achieved more easily than others, an indication of the relative expected timescales was included. The creation of the roadmap was based on the collective roundtable opinions of the authorship team who have shared AEC and sustainability experiences exceeding 100 years and 50 years, respectively. However, since this approach could be considered as being subjective, a decision was made to seek the opinions of independent AEC industry experts with sustainability experience to validate its creation and, hence, Stage Two was implemented.

In Stage Two, the Roadmap was shared via a Qualtrics questionnaire survey (recording participant details and opinions) with a panel of AEC industry-facing professionals from each of the sectors and who are based in organisations that hold ISO 14001 certification. Eligibility criteria used to include participants as experts was that they needed to be: (i) a member of an AEC professional body; (ii) hold the minimum of a Bachelor degree qualification; and (iii) employed in one of the AEC sectors for a minimum of five years and to have worked on sustainability-related projects during that time.

\section{Findings}

This section presents the outcomes of the literature review and shares the opinions of IEMA experts on the information that was extracted from the review. Subsequently, the section describes the roadmap created by the authors and shares the views of the AEC experts who proffered opinion towards its validation.

\subsection{Identification of the benefits and barriers of implementing EMS in the AEC sectors}

The PRISMA search resulted in 137 articles being screened and checked for eligibility before a final group of articles $(n=44)$ was used for the literature review (Figure 2). A 
summary of these works is presented in Table 3, highlighting the continued interest in this area across a range of sectors.

The benefits and barriers extracted from the works presented in Table 3 are listed and cross-referenced to their sources (Tables 4 and 5). These have been reviewed and the frequency of each benefit and barrier being reported is presented (Figs. 3 and 4). In terms of the benefits (Table 3 and Figure 3), the most widely reported benefits are: improved environmental performance (Owolana and Booth, 2016; Shen and Tam, 2002), improved corporate image (Shen and Tam, 2002; Turk, 2009, 2012), and compliance with regulations (Turk, 2009; Johnson, 2020), whilst some of the least reported ones are: subcontractor relations (Turk, 2009) and to facilitate trade (Sakr et al., 2010). These are primarily institutional benefits. In terms of barriers (Table 5 and Figure 4), the most widely reported ones are: cost (Shen and Tam, 2002; Babakri et al., 2003; Johnson 2020), lack of expertise (Turk, 2012; Schmidt and Osebald, 2017), and lack of training (Turk, 2009; Schmidt and Osebald, 2017). The least reported barriers are industry not being ready (Kein et al., 1999) and complexity of the standards (Turk, 2009). Once again, the barriers are institutional in their perspective. From this work, it was possible to group the benefits to enable an effective roadmap to be created from the groupings: corporate image, market share, cost saving, environmental impact, operations, compliance, and CSR. This produced a more userfriendly list in terms of benefits.

It should be noted that during the review process it became clear that the benefits and barriers can differ depending on the sector and the maturity of the sector in terms of their environmental engagement. Nonetheless, common themes were found. Researchers have highlighted the economic benefits to an organisation who choose to engage in ISO 14001 (Gavronski et al., 2008; Pokinski et al., 2003), and the environmental benefits have tended to be those that focus on cost or material savings (Haklik, 1997; Hibiki and Arimura, 2011), such as using less energy, lower waste charges, reduction in the materials used, and ensuring legal compliance, thereby avoiding fines. This is the traditional economic business approach, conforming to institutional theory (Hoffman,

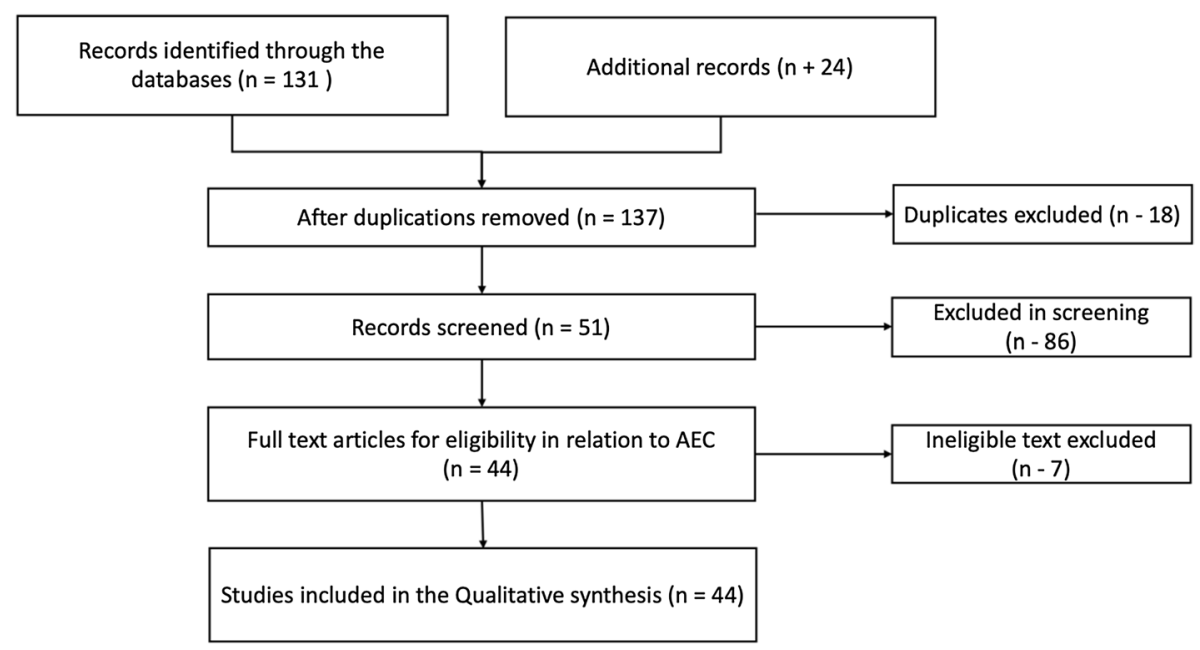

Fig. 2 Outcomes of the various stages involved in the PRISMA literature selection and identification process 


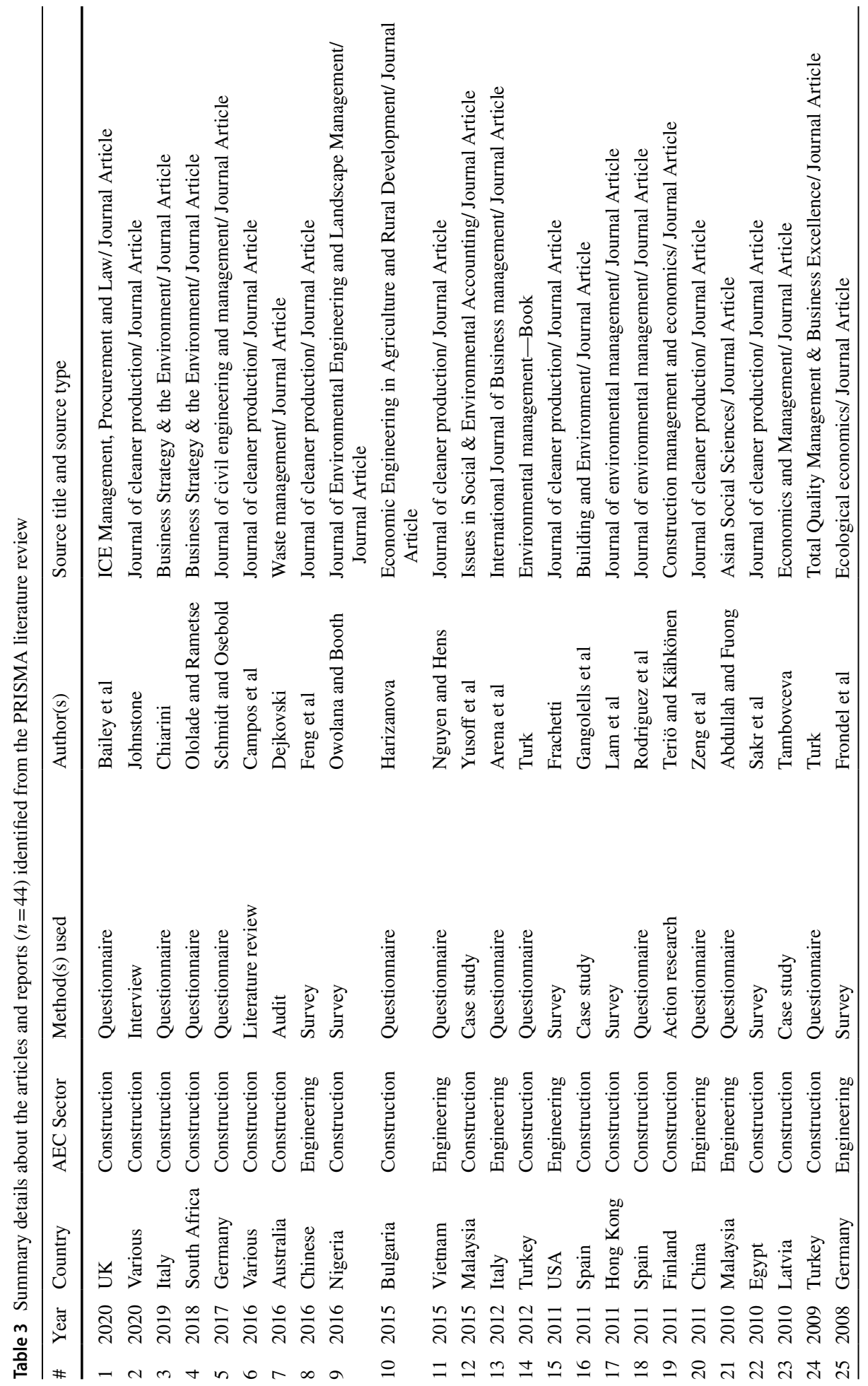




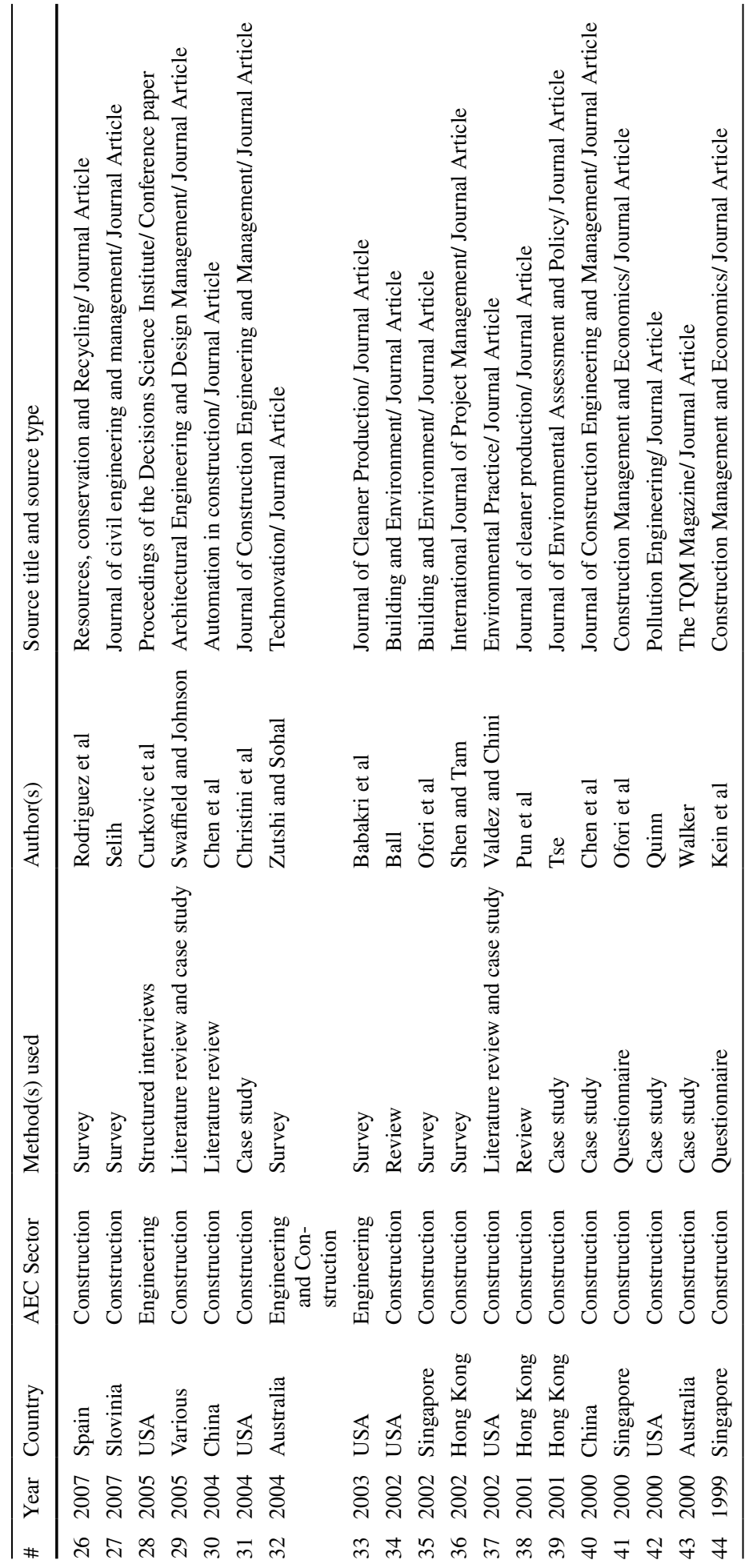


Table 4 List of the known benefits of implementing environmental management systems in the architecture, engineering and construction sectors reported in published articles and reports

Benefits of implementing environmental manageAuthors who have reported the benefits ment systems in the architecture, engineering and construction sectors

Enrich corporate and public image

Enhance image with legislators

Improve relationships with stakeholders

Credibility of the organisation

Green image

Reduced complaints

Market differentiation

Investor confidence

Competitive advantage

Long-term competitiveness

Higher profits

Market-based pressures

Stakeholder pressure

New market opportunities

Tender requirement

Equal access to green market

Facilitate trade

Pressure from competitors

Remove trade barriers

To increased market share

Customer satisfaction

Improved customer perception

Customer trust
Ofori et al. (2002); Shen and Tam (2002); Valdez and Chini (2002); Adetunji et al. (2003); Swaffield and Johnson (2005); Frondel et al. (2008); Turk (2009); Sakr et al. (2010); Teriö and Kähkönen (2011); Arena et al. (2012); Turk (2012); Harizanova (2015); Owolana and Booth (2016); Ololade and Rametse (2018); Bailey et al. (2020)

Arena et al. (2012)

Adetunji et al. (2003); Turk (2009)

Turk (2012)

Walker (2000); Shen and Tam (2002)

Owolana and Booth (2016)

Tse (2001); Owolana and Booth (2016)

Adetunji et al. (2003)

Ofori et al. (2000); Tse (2001); Ofori et al. (2002); Shen and Tam (2002); Adetunji et al. (2003); Christini et al. (2004); Curkovic et al. (2005); Turk (2009); Sakr et al. (2010); Teriö and Kähkönen (2011); Feng et al. (2016); Schmidt and Osebald (2017); Bailey et al. (2020)

Valdez and Chini (2002); Swaffield and Johnson (2005); Feng et al. (2016)

Feng et al. (2016)

Kein et al. (1999); Valdez and Chini (2002); Zeng et al. (2011)

Adetunji et al. (2003); Sakr et al. (2010)

Adetunji et al. (2003); Turk (2009)

Adetunji et al. (2003); Turk (2009); Rodríguez et al. (2011); Bailey et al. (2020)

Arena et al. (2012)

Sakr et al. (2010)

Adetunji et al. (2003); Turk (2009)

Ofori et al. (2002); Adetunji et al. (2003); Curkovic et al. (2005); Turk (2009)

Walker (2000); Turk (2009)

Kein et al. (1999); Walker (2000); Ofori et al. (2002); Curkovic et al. (2005); Selih (2007); Turk (2009); Arena et al. (2012); Turk (2012); Harizanova (2015); Ololade and Rametse (2018)

Turk (2009)

Turk (2009) 
Table 4 (continued)

Benefits of implementing environmental management systems in the architecture, engineering and construction sectors
Lower insurance costs

Cost savings through energy efficiency

Reduce resources used

Reduced carbon footprint

Reduce waste generation at source

Save costs related to water use

Better environmental information flow

Continuous improvement

Reduction in pollutants

Monitor and measure supplier performance

Environmental impact reversal awareness

Improved environmental performance

Pollution prevention

Increase public awareness of environmental issues

Reduced env impact

Reduced environmental risks

Protect the environment
Authors who have reported the benefits

Ofori et al. (2000); Tse (2001); Shen and Tam (2002); Valdez and Chini (2002); Adetunji et al. (2003); Christini et al. (2004); Swaffield and Johnson (2005); Selih (2007); Frondel et al. (2008); Turk (2009); Teriö and Kähkönen (2011); Arena et al. (2012); Harizanova (2015); Owolana and Booth (2016); Ololade and Rametse (2018); Bailey et al. (2020)

Tse (2001); Teriö and Kähkönen (2011)

Quinn (2000); Tse (2001); Shen and Tam (2002); Adetunji et al. (2003); Swaffield and Johnson (2005); Johnstone (2020)

Quinn (2000); Adetunji et al. (2003); Ofori et al. (2000); Swaffield and Johnson (2005); Turk, 2009); Bailey et al. (2020); Johnstone (2020)

Johnstone (2020)

Quinn (2000); Tse (2001); Ofori et al. (2002); Curkovic et al. (2005); Swaffield and Johnson (2005); Rodríguez et al. (2007); Turk (2009); Franchetti (2011); Teriö and Kähkönen (2011); Bailey et al. (2020); Johnstone (2020)

Quinn (2000)

Christini et al., (2004); Nguyen and Hens (2015)

Schmidt and Osebald (2017)

Turk (2009)

Turk (2009)

Shen and Tam (2002); Turk (2009)

Quinn (2000); Ball (2002); Ofori et al., (2002); Adetunji et al., (2003); Chen et al., (2004); Christini et al., (2004); Curkovic et al., (2005); Turk (2009); Gangolells et al. (2011); Arena et al. (2012); Turk (2012); Harizanova (2015); Nguyen and Hens (2015); Yusoff et al., (2015); Owolana and Booth (2016); Ololade and Rametse (2018); Bailey et al., (2020); Johnstone (2020)

Frondel et al., (2008); Owolana and Booth (2016); Bailey et al., (2020)

Shen and Tam (2002)

Quinn (2000); Ball (2002); Shen and Tam (2002); Valdez and Chini (2002); Christini et al., (2004); Turk (2009)

Turk (2009); Turk (2012)

Ofori et al., (2000); Pun et al., (2001); Ofori et al., (2002); Shen and Tam (2002); Turk (2012); Harizanova (2015); Owolana and Booth (2016); Ololade and Rametse (2018); Bailey et al., (2020); Johnstone (2020); 
Table 4 (continued)

Benefits of implementing environmental management systems in the architecture, engineering and construction sectors
Authors who have reported the benefits
Reduce waste generation at source

Increased recycling

Environmental awareness

Desire for certification

Reduce emissions

Commitment to environmental responsibility

Reduce environmental incidents

Better employee morale

Employee environmental awareness

Employee involvement and collaboration

Motivated employees

Employee satisfaction

Subcontractor relations

Involvement of senior management

Top management commitment

Increasing staff skills

Better working conditions

Efficient operations

Improved quality in product/service

Cost savings through process improvements

Improve organisational systems

Increase in efficiency and productivity

Management open to research/criticism

Higher productivity

Standardised processes

Improved risk management (H\&S)

Corporate management

Conformity

Flexible
Quinn (2000); Ofori et al., (2002); Rodríguez et al., (2007); Turk (2009); Franchetti (2011); Teriö and Kähkönen (2011); Bailey et al., (2020); Johnstone (2020)

Bailey et al., (2020); Johnstone (2020)

Turk (2009); Turk (2012); Ololade and Rametse (2018)

Turk (2009)

Turk (2009)

Turk (2009)

Turk (2009); Bailey et al., (2020)

Owolana and Booth (2016); Chiarini (2019); Bailey et al., (2020)

Christini et al., (2004); Rodríguez et al., (2007); Nguyen and Hens (2015); Yusoff et al., (2015); Owolana and Booth (2016); Johnstone (2020)

Chiarini (2019)

Yusoff et al., (2015)

Adetunji et al., (2003)

Turk (2009)

Tse (2001)

Chiarini (2019)

Christini et al., (2004); Yusoff et al., (2015); Chiarini (2019)

Ofori et al., (2002); Christini et al., (2004); Turk (2009); Schmidt and Osebald (2017); Bailey et al., (2020)

Ofori et al., (2000); Swaffield and Johnson (2005); Turk (2009); Teriö and Kähkönen (2011); Johnstone (2020)

Arena et al. (2012)

Ofori et al., (2002); Valdez and Chini (2002); Turk (2009)

Ball (2002); Christini et al., (2004); Turk (2009); Teriö and Kähkönen (2011);

Ofori et al., (2000); Pun et al., (2001)

Turk (2009)

Ofori et al., (2002)

Ofori et al., (2000); Ofori et al., (2002); Ololade and Rametse (2018)

Bailey et al. (2020); Christini et al. (2004); Ofori et al. (2000); Owolana and Booth (2016)

Quinn (2000); Adetunji et al., (2003); Christini et al., (2004); Selih (2007); Turk (2009)

Turk (2009)

Christini et al., (2004) 
Table 4 (continued)

Benefits of implementing environmental management systems in the architecture, engineering and construction sectors
Authors who have reported the benefits

$\frac{\text { Industry standards }}{\text { Compliance with regulations }}$

Liability threats

Ensuring legal compliance

Reduction in fines

Lower risk of liabilities/due diligence

Cost of non-compliance

Improved relations with regulators

Improved community relations

Social pressure (community/activists)

Increase stakeholder confidence

Social legitimacy and responsibility

Less complaints

Community participation

To improve industry/ government relations

Government support/ incentives
Bailey et al., (2020)

Kein et al., (1999); Pun et al., (2001); Adetunji et al., (2003); Chen et al., (2004); Ofori et al., (2002); Rodríguez et al., (2007); Selih (2007); Frondel et al., (2008); Turk (2009); Nguyen and Hens (2015); Dejkovski (2016); Schmidt and Osebald (2017); Ololade and Rametse (2018); Johnstone (2020)

Ofori et al., (2002)

Ofori et al., (2000); Shen and Tam (2002); Dejkovski (2016)

Shen and Tam (2002); Adetunji et al., (2003); Bailey et al., (2020)

Adetunji et al., (2003); Owolana and Booth (2016)

Adetunji et al., (2003); Ofori et al., (2002); Turk (2009); Teriö and Kähkönen (2011)

Valdez and Chini (2002)

Arena et al. (2012)

Adetunji et al., (2003); Zeng et al., (2011)

Turk (2012)

Turk (2009); Turk (2012); Ololade and Rametse (2018)

Turk (2009); Turk (2012); Bailey et al., (2020)

Shen and Tam (2002)

Adetunji et al., (2003); Arena et al. (2012)

Adetunji et al., (2003); Selih (2007)

1997), that has existed for many years. In this research, it is noted that there are both institutional and social legitimacy factors as to why a company engages in environmental management. In terms of ISO 14001, traditionally it has been used to focus on the significant aspects of the company's operations and the mitigation of negative impacts. A change in perspective from this to how positive impacts can be instigated would help companies who are compliance focused to move to society focused approaches and help deliver on projects connected to the delivery of the SDGs. However, as it is the companies who choose what the focus of their operation is and whether they choose to be sustainable or not, there would need to be an incentive to enable more to choose the more altruistic options. For instance, a grading to all ISO 14001 certificates that demonstrated a company's contribution to global issues may encourage more engagement in the SDG objectives.

This study found that there were 63 barriers to engagement with ISO 14001 from the papers reviewed, mainly in the construction sector but with a great variety in the countries involved. These factors would need to be considered in future research as potential limiting factors to the delivery of the SDGs.

One of the most often cited barriers is that of keeping pace with requirements: either of the standard or legislation. These were closely followed by the need to have 
Table 5 List of the known barriers to implementing environmental management systems in the architecture, engineering and construction sectors reported in published articles and reports

Barriers to implementing environmental management systems in the architecture, engineering and construction sectors

Negative publicity

Purely image building

Open to public scrutiny

Cost

Costs may be higher than BENEFITS

Doesn't add value

Top management commitment towards implementation

Industry not ready

Setting up management structures

Identification of env aspect/impact

Little improvement in environmental performance

Lack of link to EIA

Lack of environmentally sound technology

Lack of concern over environmental issues

No environmental improvement

Decreased competitiveness

Existing subcontractor system

Unsuitable standard

Change of existing practice

Not required for export

Public not interested

Lack of resources

Disruption to workflow

Bureaucratic
Authors who have reported the benefits

Teriö and Kähkönen (2011)

Curkovic et al., (2005); Dejkovski (2016)

Zutshi and Sohal (2004)

Kein et al., (1999); Chen et al., (2000); Ofori et al., (2000); Tse (2001); Ofori et al., (2002); Shen and Tam (2002); Valdez and Chini (2002); Babakri et al., (2003); Chen et al., (2004); Zutshi and Sohal (2004); Swaffield and Johnson (2005); Rodríguez et al., (2007); Selih (2007); Lam et al., (2011); Sakr et al., (2010); Teriö and Kähkönen (2011); Turk (2009); Turk (2012); Campos et al., (2016); Feng et al., (2016); Owolana and Booth (2016); Schmidt and Osebald (2017); Bailey et al., (2020)

Ofori et al., (2000); Ofori et al., (2002); Shen and Tam (2002); Abdullah and Fuong (2010); Ololade and Rametse (2018); Bailey et al., (2020)

Dejkovski (2016); Ololade and Rametse (2018)

Pun et al., (2001); Shen and Tam (2002); Babakri et al., (2003); Turk (2009); Rodríguez et al., (2011); Ololade and Rametse (2018)

Kein et al., (1999)

Shen and Tam (2002); Yusoff et al., (2015); Owolana and Booth (2016)

Kein et al., (1999); Abdullah and Fuong (2010)

Kein et al., (1999); Ofori et al., (2002); Babakri et al., (2003); Dejkovski (2016); Johnstone (2020)

Chen et al., (2004)

Tse (2001); Shen and Tam (2002); Owolana and Booth (2016); Bailey et al., (2020)

Babakri et al., (2003); Chen et al., (2004); Schmidt and Osebald (2017)

Ofori et al. (2002); Valdez and Chini (2002)

Shen and Tam (2002)

Tse (2001); Shen and Tam (2002); Selih (2007); Turk (2009); Sakr et al., (2010); Bailey et al., (2020); Johnstone (2020)

Tse (2001); Shen and Tam (2002)

Shen and Tam (2002); Zutshi and Sohal (2004); Yusoff et al., (2015); Owolana and Booth (2016); Bailey et al., (2020)

Shen and Tam (2002)

Chen et al., (2000); Chen et al., (2004)

Tse (2001); Babakri et al., (2003); Rodríguez et al., (2011); Feng et al., (2016)

Owolana and Booth (2016)

Kein et al., (1999); Tse (2001); Turk (2009); Tambovceva (2010) 
Table 5 (continued)

Barriers to implementing environmental management systems in the architecture, engineering and construction sectors
Authors who have reported the benefits
For sales not environmental stuff

Lack of employee involvement

Inadequate organisational structure

Employee resistance

Lack of awareness

Time

Audits

Documentation

Can use ISO 9000 to deliver objectives

Complexity of standards

Lack of knowledge about ISO 14001

Lack of support

Uncertainty of benefits

Lack of incentives
Shen and Tam (2002)

Tse (2001); Shen and Tam (2002); Valdez and Chini (2002); Swaffield and Johnson (2005); Selih (2007); Owolana and Booth (2016); Ololade and Rametse (2018); Bailey et al., (2020); Johnstone (2020)

Shen and Tam (2002); Johnstone (2020)

Shen and Tam (2002); Babakri et al., (2003); Zutshi and Sohal (2004); Turk (2009); Owolana and Booth (2016)

Ofori et al., (2002); Zutshi and Sohal (2004);

Tambovceva (2010); Ololade and Rametse (2018); Chiarini (2019)

Chen et al., (2000); Tse (2001); Shen and Tam (2002); Turk (2009); Lam et al., (2011); Terio and Kahkonen (2011); Owolana and Booth (2016); Bailey et al., (2020)

Shen and Tam (2002)

Tse (2001); Shen and Tam (2002); Zutshi and Sohal (2004); Selih (2007); Turk (2009); Owolana and Booth (2016); Schmidt and Osebald (2017); Bailey et al., (2020)

Ofori et al., (2000); Ofori et al., (2002); Turk (2012)

Turk (2009)

Kein et al., (1999); Shen and Tam (2002); Valdez and Chini (2002); Turk (2009); Turk (2012); Schmidt and Osebald (2017); Ololade and Rametse (2018)

Owolana and Booth (2016)

Ofori et al., (2000); Ofori et al., (2002); Babakri et al., (2003); Turk (2012); Campos et al., (2016)

Ofori et al., (2002); Shen and Tam (2002); Turk (2012); Bailey et al (2020)

Relies on peer pressure and management incentives, Shen and Tam (2002)

which may be ineffective

No major impacts in the sector

Shen and Tam (2002); Ololade and Rametse (2018)

Lack of guidelines

Incompatible subcontracting systems

Suppliers and subcontractors must also improve

Competitive pressures

Lack of stakeholder support
Shen and Tam (2002); Ololade and Rametse (2018)

Tse (2001); Shen and Tam (2002); Owolana and Booth (2016); Bailey et al., (2020)

Shen and Tam (2002); Zutshi and Sohal (2004); Swaffield and Johnson (2005); Owolana and Booth (2016) Bailey et al., (2020)

Shen and Tam (2002)

Ofori et al., (2000); Tse (2001); Ofori et al., (2002); Shen and Tam (2002); Zutshi and Sohal (2004); Selih (2007); Turk (2009); Turk (2012); Owolana and Booth (2016); Bailey et al., (2020); Johnstone (2020) 
Table 5 (continued)

Barriers to implementing environmental management systems in the architecture, engineering and construction sectors

Lack of stakeholder demand or pressure

Separate design and build

Lack of rigour

Focus on process, not results

Change is stressful

Sector is weak in terms of environment

Risk low

Lack of materials/technology

Need for tailor made training

Lack of experienced consultants

Lack of experience

Lack of expertise

Lack of training

Lack of knowledge

Legal ramifications

Legal issues resulting

Legal compliance

No mechanical control
Authors who have reported the benefits

Kein et al., (1999); Ofori et al., (2000); Tse (2001); Shen and Tam (2002); Selih (2007); Turk (2009); Owolana and Booth (2016); Schmidt and Osebald (2017); Bailey et al., (2020)

\section{Selih (2007)}

Lam et al., (2011)

Shen and Tam (2002)

Bailey et al., (2020)

Kein et al., (1999); Tse (2001); Shen and Tam (2002); Selih (2007); Ololade and Rametse (2018)

Shen and Tam (2002)

Tse (2001); Selih (2007); Owolana and Booth (2016)

Tse (2001); Shen and Tam (2002); Yusoff et al., (2015); Owolana and Booth (2016); Bailey et al., (2020)

Ofori et al., (2000)

Shen and Tam (2002); Rodríguez et al., (2011); Turk (2012); Owolana and Booth (2016)

Ofori et al., (2000); Ofori et al., (2002); Shen and Tam (2002); Zutshi and Sohal (2004); Turk (2009); Sakr et al., (2010); Tambovceva (2010); Turk (2012); Campos et al., (2016); Owolana and Booth (2016); Schmidt and Osebald (2017); Ololade and Rametse (2018); Bailey et al., (2020)

Tse (2001); Babakri et al., (2003); Zutshi and Sohal (2004); Swaffield and Johnson (2005); Turk (2009); Rodríguez et al., (2011); Yusoff et al., (2015); Owolana and Booth (2016); Schmidt and Osebald (2017); Ololade and Rametse (2018); Bailey et al., (2020)

Ofori et al., (2002); Shen and Tam (2002); Zutshi and Sohal (2004); Sakr et al., (2010); Tambovceva (2010); Turk (2012); Ololade and Rametse (2018)

Teriö and Kähkönen (2011)

Teriö and Kähkönen (2011)

Kein et al., (1999)

Ball (2002)

environmental expertise, the cost involved, and the lack of perceived value. All these barriers will potentially also impact on a company's willingness to engage with the SDGs.

The SDGs cover a range of sustainability issues with many underlying targets in the topic areas. From these issues, it was possible to map against the benefits of ISO 14001 to establish that the same benefits could be achieved while making a positive societal impact (Table 1). The aim of the roadmap is to enable the sector to map their 
Top Ten Benefits

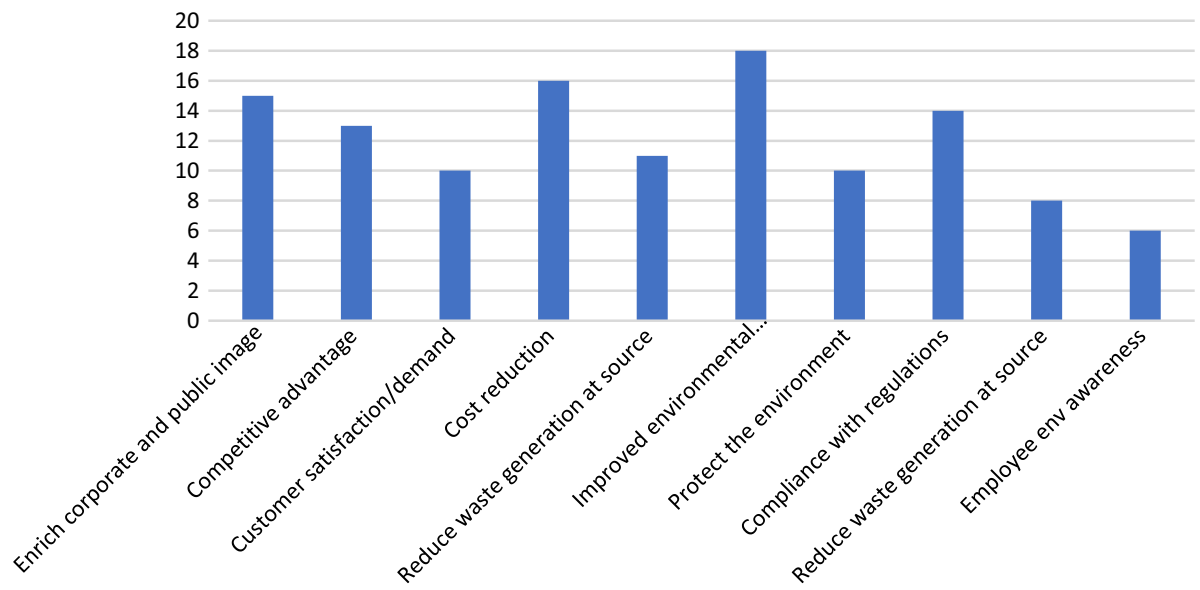

Fig. 3 Top 10 most frequently reported benefits of implementing environmental management systems in the Architecture, Engineering and Construction sectors

Top ten barriers

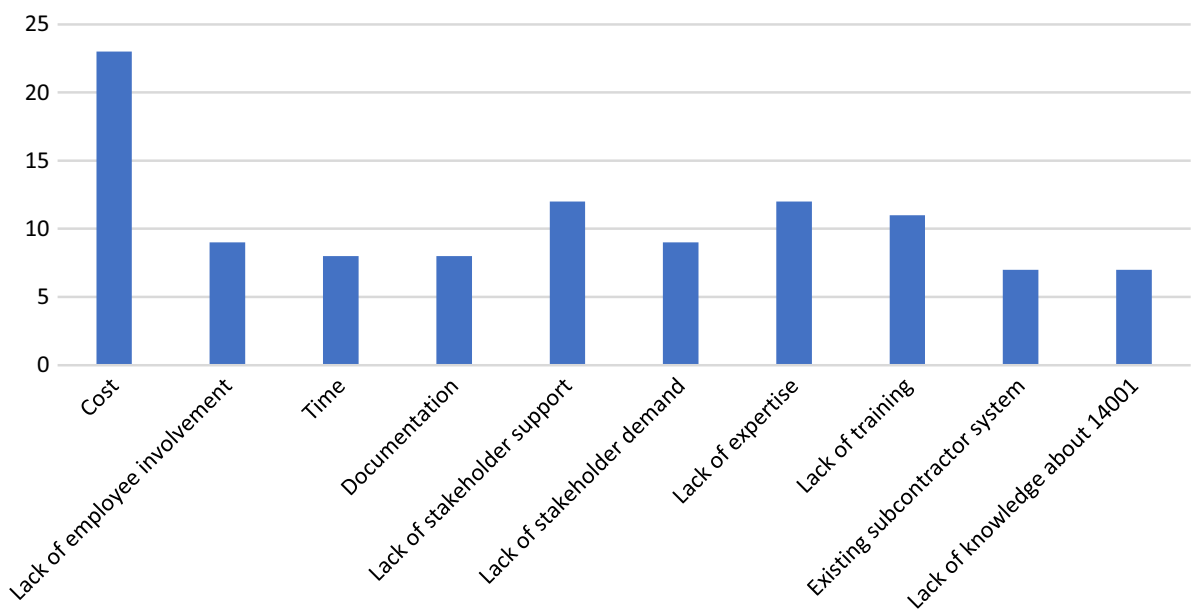

Fig. 4 Top 10 most frequently reported barriers to implementing environmental management systems in the Architecture, Engineering and Construction sectors

contribution to sustainability and to highlight the positive impacts that can be delivered through their operations. Thus, by using the SDGs in areas of operation it is possible that they can also deliver the benefits of engaging with ISO 14001. The difference would be that the SDGs enable an organisation to engage positively with the sustainability agenda outside the walls of their organisation and be seen to be making a positive difference to society. 


\subsection{Validation of the identified benefits and barriers of implementing EMS in AEC sectors}

The lists of benefits and barriers (Tables 4 and 5) extracted from the literature were presented to IEMA experts for verification as being accurate and complete. The profiles of the participants show they are all IEMA members, with the minimum of a Bachelor degree and they have all been working in environmental management roles for more than five years (Table 6).

All participants $(100 \% ; n=25)$ confirm both lists as accurate. Most participants $(84 \%$; $n=21)$ agreed that both lists were complete. Some participants kindly qualified their responses to the completeness questions by suggesting that there are other known benefits and barriers outside those extracted from the AEC literature. Whilst this is duly acknowledged, this study is focussed solely on the AEC sectors so inclusion of benefits and barriers outside the AEC sectors would not be appropriate for the purpose of inclusion in the roadmap output from this study.

Table 6 Participant profiles of the Environmental Management professionals used to validate the lists or benefits and barriers identified in the literature review

\begin{tabular}{|c|c|c|c|}
\hline Participant & $\begin{array}{l}\text { Highest academic } \\
\text { achievement }\end{array}$ & $\begin{array}{l}\text { Environmental professional } \\
\text { body membership }\end{array}$ & $\begin{array}{l}\text { Years of professional envi- } \\
\text { ronmental or sustainability } \\
\text { experience }\end{array}$ \\
\hline 1 & MSc & IEMA & $6-10$ years \\
\hline 2 & MSc & IEMA & $11-15$ years \\
\hline 3 & MSc & IEMA & $6-10$ years \\
\hline 4 & MSc & IEMA & $11-15$ years \\
\hline 5 & MSc & IEMA & $>20$ years \\
\hline 6 & MSc & IEMA & $11-15$ years \\
\hline 7 & $\mathrm{BSc}$ & IEMA & $>20$ years \\
\hline 8 & MSc & IEMA & $11-15$ years \\
\hline 9 & $\mathrm{MSc}$ & IEMA & $11-15$ years \\
\hline 10 & MSc & IEMA & $6-10$ years \\
\hline 11 & MSc & IEMA & $6-10$ years \\
\hline 12 & MSc & IEMA & $6-10$ years \\
\hline 13 & MSc & IEMA & $6-10$ years \\
\hline 14 & MSc & IEMA & $11-15$ years \\
\hline 15 & MSc & IEMA & $6-10$ years \\
\hline 16 & MSc & IEMA & $6-10$ years \\
\hline 17 & MSc & IEMA & $6-10$ years \\
\hline 18 & MSc & IEMA & $6-10$ years \\
\hline 19 & MSc & IEMA & $6-10$ years \\
\hline 20 & MBA & IEMA & $>20$ years \\
\hline 21 & MSc & IEMA & $11-15$ years \\
\hline 22 & MSc & IEMA & $6-10$ years \\
\hline 23 & MSc & IEMA & $6-10$ years \\
\hline 24 & MSc & IEMA & $6-10$ years \\
\hline 25 & MSc & IEMA & $6-10$ years \\
\hline
\end{tabular}




\subsection{Creation of a roadmap to deliver the SDGS}

The roadmap was created by mapping the benefits of ISO 14001 against the SDGs to ascertain which benefits could be delivered through engagement with the SDGs. The roadmap (Figure 5) shows 1,462 total potential cells where benefits could be achieved of which 503 were considered to produce a tangible opportunity to the organisation in terms of similar benefits to those achieved using ISO 14001. Blank cells have been excluded due to their minimal cost benefit profile and hence the following percentages are calculated from the more realisable benefits. Most of these are green $(74 \% ; n=372)$, suggesting achievable
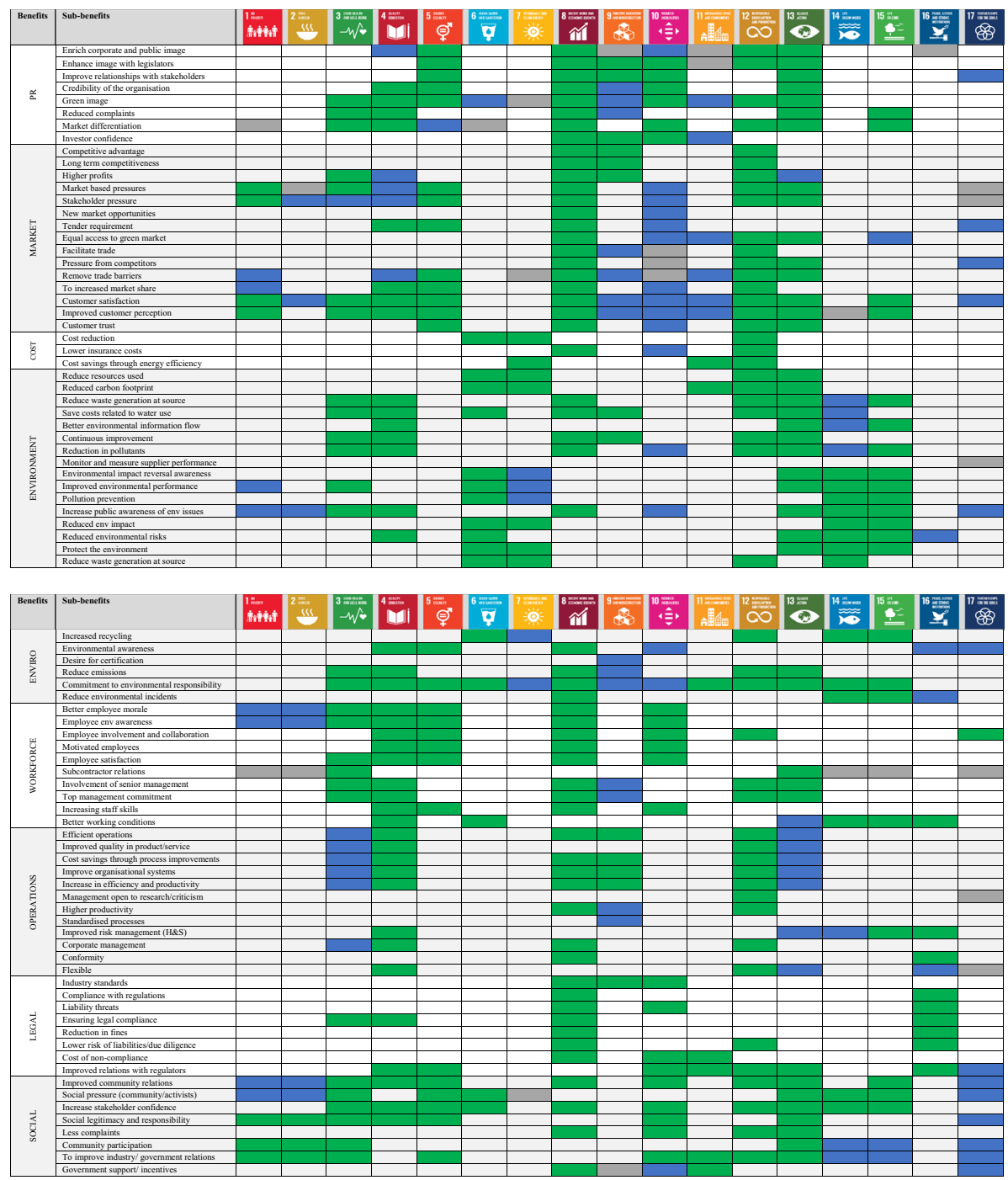

Fig. 5 Roadmap of how EMS benefits link to the SDGs ( $\checkmark$ Green block=short-term achievement; $\checkmark$ blue block $=$ medium-term achievement; $\checkmark$ grey block $=$ long-term achievement $)$ resources 
opportunities for AEC organisations operating EMS to contribute to the delivery of the SDGs and these could be achieved quite swiftly. There are blue coloured cells (equating to $21 \%$ ) and grey coloured cells (equating to 5\%) for the medium- and longer-term benefits. The intention is that organisations could use this as a tool to focus work to achieve their desired outcomes but also by contributing to the work on delivery of the SDGs.

All the EMS benefits have linkages across to the SDGs. SDGs 8, 12, and 13, link with at least one of the sub-benefits for each of the group benefits. SDG 8 links with the greatest number of sub-benefits $(n=59)$, while SDG 2 links with the least number of sub-benefits $(n=12)$. All SDGs link with at least ten of the sub-benefits, with four (SDG 4, 8, 12, and 13) linking with at least half of the benefits. The public relations, market, and social group benefits link to the most SDGs (mostly 5, 8, 10, 12). In terms of the sub-benefits: customer satisfaction, commitment to environmental responsibility, green image, improved community relations, and improved industry/government relations link to the most SDGs $(3,5,10$, $12,13)$.

\subsection{Validation of the roadmap}

After the roadmap was created by the research team, it was presented to a group of 12 AEC industry experts to validate. The group of experts are from all parts of the AEC sectors, and all met and/or exceeded each of the participant criteria detailed earlier. As with a similar study (Ezekannagha et al., 2020), where validation was sought, a small cohort of participants were invited because the profile of the experts was deemed to be an overriding factor in the validation process. Table 7 shows the professional requirements for the nine experts who shared their thoughts and opinions of the roadmap. Most of the experts have between 6 and 10 years' experience working in the AEC sectors and in some cases participants have even more experience in the sectors. All have worked on sustainability projects, and everyone had a minimum of a Bachelor degree, with the majority qualified above this level.

They were invited to review the document and to make comments about its usefulness in assisting organisations to engage with the SDG agenda. While most of the participants thought that the roadmap was useful there were requests for instructions for the roadmap to make the process simpler. This roadmap tool was thought to be of use in one of two ways, depending on if the focus is on achieving the SDGs where it will show the potential benefits of this or, if the objective is to gain the benefits and, therefore, see which SDGs would help in the achievement of these. In terms of the green, blue, and grey blocks, the green blocks are mapped to areas which area closely linked to the sector and would be easiest to achieve in the short term. The blue blocks tend to be areas outside the standard operations of this sector and will therefore require collaboration with other parties to deliver on the goal. The grey blocks are areas where it is more likely to be longer term before benefits are seen, as in the case of partnerships where the stakeholders may not be at the same point of the journey towards sustainability and therefore may not wish to be involved now but in the long term.

\section{Discussion}

This study sets out to establish if the potential benefits and barriers of ISO 14001 could facilitate the AEC sectors to move towards a more sustainable approach and whether these benefits could also be achieved within organisations while facilitating the delivery on the 


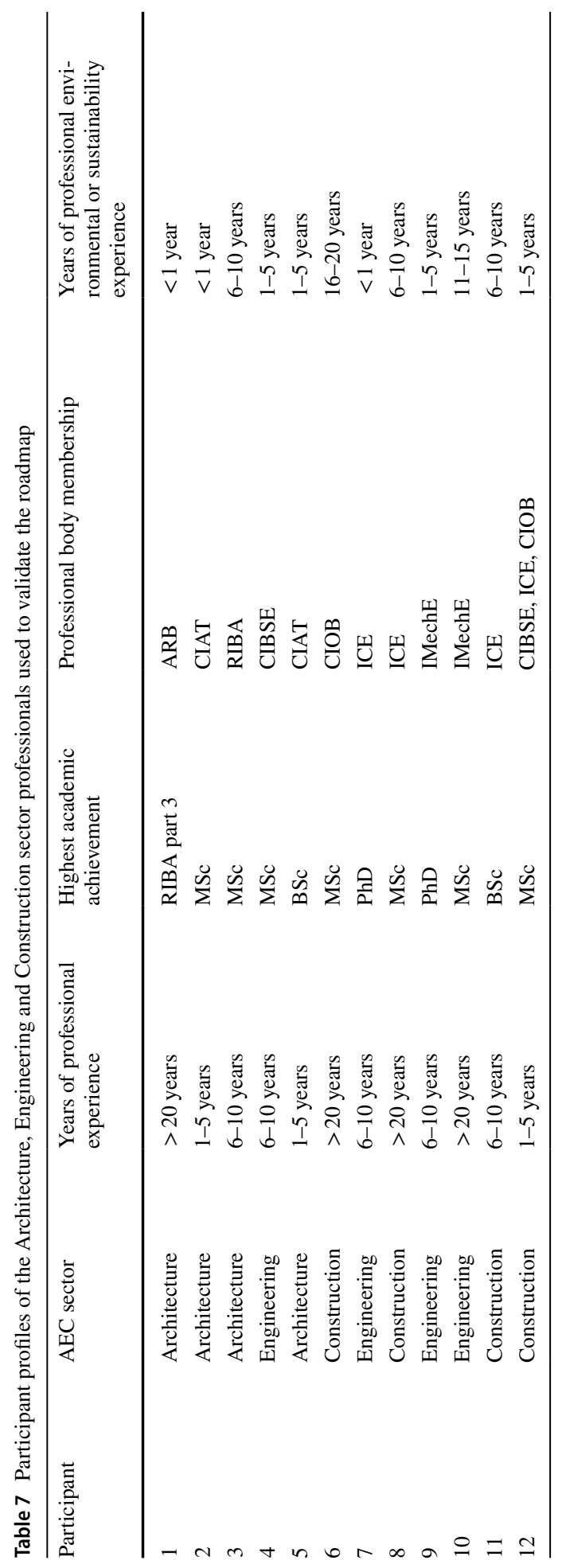


SDGs. The SDGs are a global challenge and provide a means for organisations to focus on the economic, environmental, and societal needs of the planet and to increase their social legitimacy (Suchman, 1995). The SDGs may appear a huge challenge but if all organisations contributed, the combined effect would create a greater impact. The roadmap is a means of encouraging organisations to move from their current institutional focus to a more socially legitimate position (Suchman, 1995) and enable them to consider what they are achieving through their EMS and to establish how they can achieve similar benefits while having an increased positive impact on the global issues. In many cases, this could bring bigger rewards in terms of positive stakeholder relations (Jizi, 2017), genuine positive impact on societal issues and well-being of their staff and neighbouring communities.

To enable this to happen, there needs to be a clear understanding of which SDGs will be the easiest to target first. While other researchers have highlighted SDG 1, 9, and 11 (Lynch \& Mosbah, 2017) 7, 12, and 13 (Goubran et al., 2019), it is suggested here that first and foremost the AEC sectors should be focusing on: SDG 4-quality education to ensure that the workforce has understanding about the environment and sustainability; SDG 8-decent work and economic growth; 12-responsible consumption; and 13-climate action. If these are combined with SDG 17, which is partnership for goals, this would enable construction companies, architects, planners, and government to work together to achieve sustainability. As previously noted, the construction sector has a huge impact on the sustainability of society. This roadmap is a method to improve the performance of this sector in delivering positive impacts for society. It should be acknowledged that there will be restrictions in terms of how companies can engage. Some will not have the finances or staff to make huge impacts due to their size (Hahn and Kühnen, 2013), but every person and every organisation can make some impact. It may be that they focus on small positive steps to move to a more sustainable agenda within their strategy or work on a local project. Nonetheless, whatever they do, there is clear interest in terms of sustainability from the public (Erdil et al., 2018) and this will only increase over time. Currently there are huge challenges in terms of biodiversity, food, and health throughout the world (Daszak et al., 2000) and the SDGs will help as a global focus on improving our interactions (Georgeson et al., 2017) and how we can maintain work to improve the issues.

\section{Conclusions}

Literature shows there is worldwide interest in the adoption of sustainable practices within the AEC sectors. Therefore, it is proposed that a need exists for an amalgamated approach that is relevant for the sectors and all organisations working within them. In terms of the benefits and barriers of implementation of ISO 14001 noted here are similar to research that has been conducted in other industry sectors. This study has highlighted an extensive list of benefits to support the implementation of ISO 14001 within the AEC sectors, and while it is acknowledged that there are also barriers, to move forward in a sustainable manner the use of ISO 14001 as a framework would enable companies to focus on delivery of SDG objectives. This linking of the benefits of ISO 14001 to the SDGs in a roadmap has shown how organisations could help in the delivery of the SDGs. There is a general desire amongst the global population for sectors to be seen as being more responsible in terms of sustainability. The market mechanisms, however, limit the options in terms of what can be delivered, and it is suggested here that the standards could be used more effectively. One potential way forward is for the professional bodies to push for a level to be created for 
their individual sectors, that companies could then sign up to. A gold standard: they could gain a sector specific badge, meaning, that while organisations can use an EMS for the benefit of the impacts of the organisation and monitoring of their progress; they could also utilise it to demonstrate their commitment to the SDGs, by going above and beyond the standard.

If the AEC sectors are to play a leading role in the journey to sustainability, there is a need for a clear delivery plan for achieving the SDGs. This would help to ensure not just environmental survival but social and economic success against issues such as climate change and the resultant migration of populations. The sectors, need to work on the SDGs and to align with the 5 Ps: people, planet, prosperity, peace, and partnership, which require actions to be taken by a range of stakeholders including governments and businesses to go beyond the purely environmental objectives of sustainable development. This provides a huge opportunity for the AEC sectors to be ahead of the curve in terms of using the roadmap to help demonstrate the economic viability of delivery of the SDGs and the resulting social legitimacy.

As the SDGs will benefit the whole of society, it must be remembered that the achievement of these goals will result in an increased standard of living for all; everyone will benefit. Going forward it would be useful to understand:

- The impact of the roadmap when used by an organisation to focus on the delivery of the most relevant SDGs.

- An investigation into the opportunities and challenges of using the roadmap within the sector.

- Whether the roadmap changes an organisations perspective on the deliverability of the SDGs.

- Whether the roadmap could be focused on the national and local issues to gain a true perspective of where society is in terms of sustainability.

- How the roadmap could be used in other sectors that have an impact on a global scale.

- How the barriers to implementation of ISO 14001 may delay the delivery of SDGs through businesses.

Industries such as construction are dependent on the environment, and therefore, it would be expected that they should be amenable to promoting sustainability, not just in terms of their operations but also in terms of how they interact with the communities that are situated around their operations. More research is needed in the application of the roadmap in practical terms to test the validity of the design and use. It is suggested that this should be a first step to understand the usefulness of the roadmap in helping organisations assess where they can make positive changes and how these can be highlighted to stakeholders.

This roadmap will improve the opportunities for organisations to promote their involvement with the local community, which will promote social legitimacy and allow stakeholders to have an increasingly transparent view of the company's sustainable performance. It will enable the process to highlight any conflicts that have occurred and how the response to these conflicts was appropriate and had been justified. This would result in a system which not only enables the SDGs to be worked towards on a global scale, but also the actions and impacts of those organisations who are engaging can be measured, recorded, and actions justified, benefiting society, the environment, and the economic performance of the organisation involved, thereby, increasing both their institutional and social validity. Data provided to the sector bodies from the organisations would deliver more information 
on how their sectors are progressing in terms of the SDGs and demonstrate to all stakeholders which sectors and particular organisations are truly committed to sustainability.

Acknowledgements All the authors are incredibly grateful for the feedback provided by the anonymous reviewers on the initial submitted version of this paper.

Authors' contributions All authors contributed to the study conception and design. Material preparation, data collection, and analysis were performed by RH, CB, and AMM. The first draft of the manuscript was written by RH, and all authors commented on previous versions of the manuscript. All authors read and approved the final manuscript.

Data availability Available on request.

\section{Declarations}

Conflict of interest The authors declare that they do not have any conflict of interest.

Open Access This article is licensed under a Creative Commons Attribution 4.0 International License, which permits use, sharing, adaptation, distribution and reproduction in any medium or format, as long as you give appropriate credit to the original author(s) and the source, provide a link to the Creative Commons licence, and indicate if changes were made. The images or other third party material in this article are included in the article's Creative Commons licence, unless indicated otherwise in a credit line to the material. If material is not included in the article's Creative Commons licence and your intended use is not permitted by statutory regulation or exceeds the permitted use, you will need to obtain permission directly from the copyright holder. To view a copy of this licence, visit http://creativecommons.org/licenses/by/4.0/.

\section{References}

Abanda, H., Vidalakis, C., Oti, A. H., \& Tah, J. H. M. (2015). A critical analysis of building information modelling systems used in construction projects. Advances in Engineering Software, 90, 183-201.

Abdullah, H., \& Fuong, C. C. (2010). The implementation of ISO 14001 environmental management system in manufacturing firms in Malaysia. Asian Social Sciences, 6(3), 100-107.

Ade, R., \& Rehm, M. (2019). The unwritten history of green building rating tools: A personal view from some of the 'founding fathers.' Building Research \& Information, 48(1), 1-17. https://doi.org/10. 1080/09613218.2019.1627179

Alawneh, R., Mohamed Ghazali, F. E., Ali, H., \& Asif, M. (2018). Assessing the contribution of water and energy efficiency in green buildings to achieve United Nations Sustainable Development Goals in Jordan. Building and Environment, 146, 119-132.

Allen, C., Metternicht, G., \& Wiedmann, T. (2019). Prioritising SDG targets: Assessing baselines, gaps and interlinkages. Sustainability Science, 14(2), 421-438.

Arena, M., Azzone, G., \& Platti, M. (2012). ISO 14001: Motivations and benefits in the Italian metal industry. International Journal of Engineering Business Management, 4(41), 1-9.

Arimura, T. H., Hibbiki, A., \& Katayama, H. (2008). Is a voluntary approach an effective environmental policy instrument? A case for environmental management systems. Journal of Environmental Economics and Management, 53(3), 281-295.

Babakri, K. A., Bennett, R. A., \& Franchetti, M. (2003). Critical factors for implementing ISO 14001 standard in United States industrial companies. Journal of Cleaner Production, 11, 749-752.

Bailey, M., Booth, C. A., Horry, R., Vidalakis, C., Mahamadu, A.-M., \& Awuah, K. G. B. (2020). Opinions of small and medium UK construction companies on environmental management systems. Proceedings of the Institution of Civil Engineers- Management, Procurement and Law. ICE Publications., $174(1), 23-34$.

Ball, J. (2002). Can ISO 14001 and eco-labelling turn the construction industry green?". Building and Environment, 37, 421-428.

Berardi, U. (2012). Sustainability assessment in the construction sector: Rating systems and rated buildings. Sustainable Development, 20(6), 411-424. 
Blackwell, A.F., Phaal, P., Eppler, M. and Crilly, N. (2008) Strategy Roadmaps: New Forms, New Practices, Diagrammatic Representation and Inference, $5^{\text {th }}$ International Conference. Diagrams 2008, Herrsching, Germany, September 19-21, Proceedings.

Bon, R., \& Hutchinson, K. (2010). Sustainable construction: Some economic challenges. Build Res Inf., 28(5-6), 310-314.

Bowen, G. A. (2009). Document Analysis as a Qualitative Research Method. Qualitative Research Journal, 9(2), 27-40.

Boyko, C. T., Gaterell, M. R., Barber, A. R. G., Brown, J., Bryson, J. R., \& Butler, D. (2012). Benchmarking sustainability in cities: The role of indicators and future scenarios. Global Environmental Change, 22(1), 245-254.

Brown, M. (2016). Futurestorative: Working towards a new sustainability. RIBA Publishing.

Bryman, A. and Bell, E. (2015) Business Research Methods, $4^{\text {th }}$ Edition, Oxford University Press, pg. 27.

BSi. . (2015). ISO 14001 Environmental Management Standard. British Standards Institute.

Caldés, N. and Rodriguez-Serrano, I. (2018) Potential contribution of concentrated solar power in meeting the sustainable development goals. AIP Conf Proc., 2033:120001.

Campos, L. M. S., Trierweiller, A. C., de Carvalho, D. N., \& Selih, J. (2016). Environmental management systems in the construction industry: A review. Environmental Engineering and Management Journal, 15(2), 453-470.

Chen, Z., Li, H., \& Wong, C. T. C. (2000). Environmental Management of Urban Construction Projects in China. Journal of Construction Engineering and Management, 126(4), 320-324.

Chen, Z., Li, H., \& Hong, J. (2004). An integrative methodology for environmental management in construction. Automation in Construction, 13(5), 621-628.

Chiarini, A. (2019). Factors for succeeding in ISO 14001 implementation in Italian construction industry. Business Strategy and the Environment, 28(5), 794-803.

Christini, G., Fetsko, M., \& Hendrickson, C. (2004). Environmental Management Systems and ISO 14001 Certification for Construction Firms. Journal of Construction Engineering and Management, 130(3), 330-336.

Corbin, J., \& Strauss, A. (2008). Basics of qualitative research: Techniques and procedures for developing grounded theory (3rd ed.). Sage.

Cucuzzella, C. (2009). The limits of current evaluation methods in a context of sustainable design: Prudence as a new framework". Int J Des Eng., 2(3), 243-261.

Cucuzzella, C. (2016). Creativity, sustainable designing and risk management. Journal of Cleaner Production, 135, 1548-1558.

Curkovic, S., Sroufe, R., \& Melnyk, S. (2005). Identifying the factors which affect the decision to attain ISO 14000. Journal of Energy, 30, 1387-1407.

da Silva, S. L. C., \& Amaral, F. G. (2019). Critical factors of success and barriers to the implementation of occupational health and safety management systems: A systematic review of literature. Safety Science, 117, 123-132.

Daszak, P., Cunningham, A. A., \& Hyatt, A. D. (2000). Emerging infectious diseases of wildlife: Threats to Biodiversity and Human Health. Science, 287(5452), 443-449.

David, P. (1985). Clio and the economics of QWERTY. Economic History, 75, 227-332.

Dejkovski, N. (2016). Assessing the environmental performance of construction materials testing using EMS: An Australian study. Waste Management Management (elmsford), 56, 359-366.

Di Foggia, G. (2018). (2018) Energy efficiency measures in buildings for achieving sustainable development goals. Heliyon. https://doi.org/10.1016/j.heliyon.2018.e00953

Ding, G. K. C. (2008). Sustainable construction-The role of environmental assessment tools. Journal of Environmental Management, 86(3), 451-464.

Dyllick, T., \& Muff, K. (2015). Clarifying the Meaning of Sustainable Business: Introducing a Typology from Business-as-Usual to True Business Sustainability. Organ Environ, 29(2), 156-74.

Erdil, N. O., Aktas, C. B., \& Arani, O. M. (2018). Embedding sustainability in lean six sigma efforts. Journal of Cleaner Production, 198, 520-529.

Erdos, L. (2019). David Attenborough - the grand old man of Natural History Filmmaking. Green Heroes. https://doi.org/10.1007/978-3-030-31806-2_28

Ezekannagha, O., Drimie, S., von Fintel, D., \& Maziya-Dixon, B. (2020). Validation of a roadmap for mainstreaming nutrition-sensitive interventions at state level in Nigeria. Nutrition Journal, 19(1), 1-10.

Feng, T., Cai, D., Wang, D., \& Zhang, X. (2016). Environmental management systems and financial performance: The joint effect of switching cost and competitive intensity. Journal of Cleaner Production, 113, 781-791. https://doi.org/10.1016/j.jclepro.2015.11.038 
Franchetti, M. (2011). ISO 14001 and solid waste generation rates in US manufacturing organisations: An analysis of relationship. Journal of Cleaner Production, 19, 1104-1109.

Frondel, M., Horbach, J., \& Rennings, K. (2008). What triggers environmental management and innovation? Empirical Evidence for Germany. Ecological Economics, 66(1), 153-160.

Gade, A.N. and Opoku, A. (2020) Challenges for implementing the sustainable development goals in the Danish construction industry: Building owners' perspective. In Schott, L and Neilson, C.J. (Eds) Proceedings of the $36^{\text {th }}$ Annual ARCOM Conference, 7-8 September 2020, UK, Association of Researchers in Construction Management, 615-624.

Gangolells, M., Casals, M., Gassó, S., Forcada, N., Roca, X., \& Fuertes, A. (2011). Assessing concerns of interested parties when predicting the significance of environmental impacts related to the construction process of residential buildings. Building and Environment, 46(5), 1023-1037.

Gavronski, I., Ferrer, G., \& Paiva, E. (2008). ISO 14001 certification in Brazil: Motivations and benefits. Journal of Cleaner Production, 16, 87-94.

Georgeson, L., Maslin, M., \& Poessinouw, M. (2017). The global green economy A review of concepts definitions measurement methodologies and their interactions. Geo Geography and Environment, 4(1), e00036.

Gibberd, J. (2015). Measuring capability for sustainability: The Built Environment Sustainability Tool (BEST). Build Res Inf., 43(1), 49-61.

Goubran, S., \& Cucuzzella, C. (2019). Integrating the Sustainable Development Goals in building projects. Journal of Sustainable Research, 1, e190010.

Goubran, S., Masson, T., \& Caycedo, M. (2019). Evolutions in Sustainability and Sustainable Real Estate. In T. Walker, C. Krosinsky, L. N. Hasan, \& S. D. Kibsey (Eds.), Sustainable Real Estate (pp. 11-31). Palgrave Macmillan.

Gusmão Caiado, R. G., Leal Filho, W., Quelhas, O. L. G., de Mattos, L., Nascimento, D., \& Ávila, L. V. (2018). A literature-based review on potentials and constraints in the implementation of the sustainable development goals. Journal of Cleaner Production, 198, 1276-1288.

Hahn, R., \& Kühnen, M. (2013). Determinants of sustainability reporting: A review of results, trends, theory, and opportunities in an expanding field of research. Journal of Cleaner Production, in Press,. https://doi.org/10.1016/j.jclepro.2013.07.005

Haklik, J.E. (1997) ISO 14000 Environmental management: benefiting companies, saving the environment. Business Access Online, April.

Harizanova, H. (2015). Implementation of ISO 14001 in Bulgaria. Scientific Papers Series Management, Economic Engineering in Agriculture and Rural Development, 15(1), 193-198.

Hibiki, A., \& Arimura, T. H. (2011). Case study on Adoption of Environmental Management System and Environmental Management Practices in Japan. International Journal of Sustainable Innovations, $1(1), 8-15$.

Hoffman, A. J. (1997). From heresy to dogma: An institutional history of corporate environmentalism. New Lexington Press.

Hudson, L. A., \& Ozanne, J. L. (1988). Alternative ways of seeking knowledge in consumer research. $J$. Consumer Res., 14, 508-521.

Jizi, M. (2017). The influence of Board Composition on sustainable Development Disclosure. Business Strategy and the Environment, 26(5), 640-655.

Johnstone, L. (2020). The construction of environmental performance in ISO 14001-certified SMEs. Journal of Cleaner Production, 263, 121559. https://doi.org/10.1016/j.jclepro.2020.121559

Jones, S.A. and Laquidara-Carr, D. editors. (2018) World green building trends 2018-Smart market report. Bedford (US): Dodge Data \& Analytics; pp.80.

Jung, J., Petkanic, P., Nan, D., \& Kim, J. H. (2020). When a girl awakened the world: A user and social message: Analysis of Greta Thunberg”. Sustainability, 12, 2707. https://doi.org/10.3390/su12072707

Kein, A. T. T., Ofori, G., \& Briffett, C. (1999). ISO 14000: Its relevance to the construction industry in Singapore and its potential as the next industry milestone. Construction Management and Economics, 17, 449-461.

Lam, P. T. I., Chan, E. H. W., Chau, E. H. W., Poon, C. S., \& Chun, K. P. (2011). Environmental management systems vs green specifications: How do they complement each other in the construction industry? Journal of Environmental Management, 92, 788-795.

Le Blanc, D. (2015). Towards integration at last? The sustainable development goals as a network of targets. Sustainable Development, 23(3), 176-187.

Liberati, A., Altman, D. G., Tetzlaff, J., Mulrow, C., Gotzsche, P. C., Ioannisis, J. P. A., Clarke, M., Devereaux, P. J., Kleijnen, J., \& Moher, D. (2009). The PRISMA statement for reporting systematic reviews and meta-analysis of studies that evaluate healthcare interventions: Explanation and elaboration. BMJ, 339, 2700. https://doi.org/10.1136/bmj.b2700 
Lynch, A. J., \& Mosbah, S. M. (2017). Improving local measures of sustainability: A study of built-environment indicators in the United States. Cities, 60, 301-313.

Maes, M. J. A., Jones, K. E., Toledano, M. B., \& Milligan, B. (2019). Mapping synergies and trade-offs between urban ecosystems and the sustainable development goals. Environmental Science \& Policy, 93, 181-188.

Mattoni, B., Guattari, C., Evangelisti, L., Bisegna, F., Gori, P., \& Asdrubali, F. (2018). Critical review and methodological approach to evaluate the differences among international green building rating tools. Renewable and Sustainable Energy Reviews, 82, 950-960.

McDonough, W., \& Braungart, M. (2002). Cradle to Cradle: Remaking the way we make things. North Point Press.

Moher, D., Liberati, A., Tetzlaff, J. and Altman, D.G: The PRISMA Group. (2009). Preferred Reporting Items for Systematic Reviews and Meta-Analyses The PRISMA Statement. Annals of Internal Medicine, 151(4), 264.

Moyer, J. D., \& Bohl, D. K. (2018). Alternative pathways to human development: Assessing trade-offs and synergies in achieving the Sustainable Development Goals. Futures, 105, 199-210.

Næss, P. (1994). Normative planning theory and sustainable development. Scand Hous Plan Res., 11(3), $145-167$.

Nguyen, Q. A., \& Hens, L. (2015). Environmental performance of the cement industry in Vietnam: The influence of ISO 14001 certification.". Journal of Cleaner Production, 96, 362-378.

Nishitani, K. (2009). An empirical study of the initial adoption of ISO 14001 in Japanese manufacturing firms. Ecological Economics, 68, 669-679.

Ofori, G., Briffett, C., Gang, G., \& Ranasinghe, M. (2000). Impact of ISO 14000 on construction companies in Singapore. CoNstruction Management and Economics., 18, 935-947.

Ofori, G., Gang, G., \& Briffett, C. (2002). Implementing environmental management systems in construction: Lessons from quality systems. Building and Environment, 37, 1397-1407.

Ololade, O. O., \& Rametse, P. P. (2018). Determining factors that enable managers to implement an environmental management system for sustainable construction: A case study in Johannesburg. Business Strategy \& the Environment, 27, 1720-1732.

Orrù, M., Biggart, N.W. and Hamilton, G. . (1991). Organizational isomorphism in East Asia. In W. W. Powel \& P. J. DiMaggio (Eds.), (1991) The New Institutionalism in Organizational Analysis (pp. 361-389). University of Chicago Press.

Othman, A. and Nadim, W. (2010) Towards Establishing an International Sustainability Index for the Construction Industry: A Literature Review. Proceedings of the First International Conference on Sustainability and the Future. The British University in Egypt, Cairo.

Owolana, V. O., \& Booth, C. A. (2016). Stakeholder perceptions of the Benefits and Barriers of implementing Environmental Management systems in the Nigerian Construction Industry. Journal of Environmental Engineering and Landscape Management, 24(2), 79-89.

Pesce, M., Shi, C., Critto, A., Wang, X., \& Marcomini, A. (2018). SWOT Analysis of the Application of International Standard ISO 14001 in the Chinese Context A Case Study of Guangdong Province. Sustainability, 10(9), 3196-3215.

Pokinski, B., Dahlgaard, J. J., \& Eklund, J. A. E. (2003). Implementing ISO 14001 in Sweden: Motives, benefits and comparisons within ISO 9000. International Journal of Quality and Reliability Management, 20(5), 585-606.

Pun, K. F., Hui, I. K., \& Lee, W. K. (2001). An EMS approach to environmentally friendly construction operations. The TQM Magazine, 13(2), 112-119.

Quinn, B. (2000). Contractor's Mobile Workforce No Barrier to EMS. Pollution Engineering, 32(9), $41-42$.

Randolph, J. (2009). A guide to writing a dissertation literature review" Practical Assessment. Research and Evaluation, 14(13), 2-13.

Rodríguez, G., Alegre, F. J., \& Martínez, G. (2007). The contribution of environmental management systems to the management of construction and demolition waste: The case of the Autonomous Community of Madrid (Spain). Resources, Conservation \& Recycling, 50(3), 334-349.

Rodríguez, G., Alegre, F. J., \& Martínez, G. (2011). Evaluation of environmental management resources (ISO 14001) at civil engineering construction worksites: A case study of the community of Madrid. Journal of Environmental Management, 92(7), 1858-1866.

Sakr, D., Sherif, A., \& El-Haggar, S. M. . (2010). Environmental Management Systems awareness: An investigation of top 50 contractors in Egypt. Journal of Cleaner Production, 18, 210-218.

Salvia, A. L., Leal Filho, W., Brandli, L. L., \& Griebeler, J. S. (2019). Assessing research trends related to Sustainable Development Goals: Local and global issues. Journal of Cleaner Production, 208, 841-849. 
Schmidt, J.-S., \& Osebold, R. (2017). Environmental management systems as a driver for sustainability: State of implementation, benefits and barriers in German construction companies. Journal of Civil Engineering and Management, 23(1), 150-162.

Scoones, I. (2007). Sustainability. Development in Practice, 17(4-5), 589-596. https://doi.org/10.1080/ 09614520701469609

Selih, J. (2007). Environmental management systems and construction SMES: A case study for Slovenia. Journal of Civil Engineering and Management, 13(3), 217-226.

Shah, M.M. (2008) Encyclopaedia of Ecology. Science Direct, Pg. 3443-3446.

Shen, L. Y., \& Tam, V. W. Y. (2002). Implementation of environmental management in the Hong Kong construction industry. International Journal of Project Management, 20, 535-544.

Spangenberg, J. H., Pfahl, S., \& Deller, K. (2002). Towards indicators for institutional sustainability: Lessons from an analysis of Agenda 21. Ecological Indicators, 2(1-2), 61-77.

Suchman, M. C. (1995). Managing Legitimacy: Strategic and Institutional Approaches. Academy of Management Review, 20(3), 571-610.

Swaffield, L. M., \& Johnson, G. A. (2005). The Financial Benefits of Implementing ISO 14001 within Construction Contracting Organizations. Architectural Engineering and Design Management, 1(3), 197210. https://doi.org/10.1080/17452007.2005.9684593

Tambovceva, T. (2010). Assessment model of Environmental Management: A case study of construction enterprises in Latvia. Economics and Management, 15, 799-806.

Teriö, O., \& Kähkönen, K. (2011). Developing and implementing environmental management systems for small and medium-sized construction enterprises. Construction Management and Economics, 29(12), 1183-1195.

The Circle Economy (2020) THE Circularity Gap Report https://www.circle-economy.com/resources/circu larity-gap-report-2020.

Thuesen, C. and Opoku, A. (2018) A call for action: Constructing solutions for the sustainable development goals, working paper available from http:www.arcom.ac.uk/-docs/archive/2018-workingpapers.pdf.

Tosun, J., \& Leininger, J. (2017). Governing the interlinkages between the sustainable development goals: Approaches to attain policy integration. Global Challenges, 1(9), 1700036.

Tse, R. Y. C. (2001). The implementation of EMS in construction firms: Case study in Hong Kong. Journal of Environmental Assessment Policy and Management, 3(2), 177-194.

Turk, A. (2009). ISO 14000 environmental management system in construction: An examination of its application in Turkey. Total Quality Management \& Business Excellence, 20(7), 713-733.

Turk, A.M. (2012) The pros and cons of ISO 14000 environmental management systems (EMS) for Turkish Construction Firms in Dupont, H. C.(ed) Environmental Management, pp 179-196.

UN (2020b) Population. https://www.un.org/en/sections/issues-depth/population/

UN (2019) Environmental programme https://www.unenvironment.org/news-and-stories/story/were-gobbl ing-earths-resources-unsustainable-rate

UN (2020a) Sustainable Goals knowledge platform. https://sustainabledevelopment.un.org/milestones/unced

UN (United Nations) World Social Report (2020c). Available at https://www.un.org/development/desa/ dspd/wp-content/uploads/sites/22/2020/01/World-Social-Report-2020-FullReport.pdf

United Nations (2015) Transforming our world. https://www.un.org/sustainabledevelopment/blog/2015/08/ transforming-our-world-document-adoption/

Valdez, H. E., \& Chini, A. R. (2002). ISO 14001 Standards and the US Construction Industry. Environmental Practice, 4(4), 210-219.

Villeneuve, C., Tremblay, D., Riffon, O., Lanmafankpotin, G., \& Bouchard, S. (2017). A Systemic Tool and Process for Sustainability Assessment. Sustainability, 9(10), 1909. https://doi.org/10.3390/su9101909

Walker, D. H. T. (2000). Client/customer or stakeholder focus? ISO 14000 EMS as a construction industry case study. The TQM Magazine, 12(1), 18-26.

Yusoff, S., Nordin, R., \& Yusoff, H. (2015). Environmental Management Systems (EMS) ISO 14001 implementation in construction industry: A Malaysian case study. Issues in Social \& Environmental Accounting, 9(1), 18-31.

Zeng, S. X., Meng, X. H., Zeng, R. C., Tam, C. M., Tam, V. X. Y., \& Jin, T. (2011). How environmental management driving forces affect environmental and economic performance of SMEs: A study in the Northern China district. Journal of Cleaner Production, 19, 1425-1437.

Zutshi, A., \& Sohal, A. (2004). A study of the environmental management system (EMS) adoption process within Australian organisations 2: Role of stakeholders. Technovation, 24, 335-357.

Publisher's Note Springer Nature remains neutral with regard to jurisdictional claims in published maps and institutional affiliations. 


\section{Authors and Affiliations}

\section{Rosemary Horry ${ }^{1,2}$ (D) Colin A. Booth ${ }^{2}$ (D) Abdul-Majeed Mahamadu2 (D) Patrick Manu ${ }^{3}$ (D) Panos Georgakis ${ }^{4}$ (D)}

Colin A. Booth

colin.booth@uwe.ac.uk

Abdul-Majeed Mahamadu

abdul.mahamadu@uwe.ac.uk

Patrick Manu

Patrick.manu@manchester.ac.uk

Panos Georgakis

P.Georgakis@wlv.ac.uk

1 The College of Science and Engineering, University of Derby, Kedleston Road, Derby DE22 1GB, UK

2 Centre for Architecture and Built Environment Research (CABER), Faculty of Environment and Technology, University of the West of England (UWE), Coldharbour Lane, Bristol BS16 1QY, UK

3 Department of Mechanical, Aerospace and Civil Engineering, University of Manchester, Pariser Building, Sackville Street, Manchester M13 9P, UK

4 Faculty of Science and Engineering, University of Wolverhampton, Wulfruna Street, Wolverhampton WV1 1LY, West Midlands, UK 